\title{
[20ing
}

\section{THE UNITED NATIONS}

\section{Leland $M$. Goodrich}

\section{Columbia University}

"He traces with clarity and precision the origins of the United Nations, the competing grand designs, the debates over structure and function, and the politics of the new organization. He approaches these issues with a sovereign understanding that few, if any, of our present-day writers can match. Having laid the foundations, he turns to examine the simultaneous evolution and devolution of the agencies and powers of the United Nations. His section on 'common values' is circumspect and full of insights. His analysis of membership and the deadlock over admissions is, I feel, unexceptionable.

"The core of the political analysis comes in the discussion of 'The Structure of Power and Influence.' This is political science at its best, for Goodrich studies the various United Nations organs over against the political forces that shaped them in ways the framers could not possibly have fully envisaged. . . The central problems of the United Nations-peaceful settlement, disarmament, human rights, economic and social welfare and dependent peoples-are described and evaluated with wisdom and intelligence. Finally, his critique of the accomplishments of the United Nations and its future make sober and informative reading . . . a study of enduring value that every graduate and undergraduate student, professor and diplomat should peruse with the same care the author has chosen his words."

-KENNETH W. THOMPSON in the Political Science Quarterly (Dec., '59)

\section{THOMAS Y. CROWELL COMPANY}

432 Park Avenue South, New York 16, N. Y. 